\title{
Suitability of NDVI index to pea condition evaluation at diverse phosphorus fertilization
}

\author{
Janina Gospodarek, ${ }^{1}$ Agnieszka Klimek-Kopyra, ${ }^{2}$ Milena Rusin ${ }^{1}$ \\ ${ }^{1}$ Department of Microbiology and Biomonitoring, University of Agriculture in Krakow, Poland; \\ ${ }^{2}$ Institute of Plant Production, Department of Crop Production, University of Agriculture in Krakow, Poland
}

\begin{abstract}
In this 3-year study the suitability of the normalized differenced vegetation index (NDVI) to the evaluation of pea plant infestation by aphids and expected seeds yield was investigated. The effect was assessed in the conditions of the increasing doses of phosphorus fertilization $\left(0,70\right.$, and $\left.140 \mathrm{~kg} \mathrm{P}_{2} \mathrm{O}_{5} \mathrm{ha}^{-1}\right)$ and in the different pea aphid (Acyrthosiphon pisum Harris) occurrence on six various cultivars of pea. Independent of the dose, the phosphorus fertilization supported the occurrence of aphids on pea plants of Batuta, Model, and Protecta cultivars where in Tarchalska and Mecenas cultivars only the standard dose $\left(70 \mathrm{~kg} \mathrm{ha}^{-1}\right)$ showed such effect. NDVI index was not clearly, unambiguously correlated to the intensity of $A$. pisum occurrence. Such factors as the deficiency or excessive amount of phosphorus, as well as meteorological conditions and the cultivar of host plant had the greater effect on its value than the presence of aphids. All this testifies that the NDVI index is not reliable indicator of aphid occurrence on pea, however it can offer a promising method to select the cultivars under sub-opitmal conditions. The seed yield was strongly related to agronomical factors (fertilization, cultivars) and plant (NDVI) variable, while marginally to environmental variable (aphids).
\end{abstract} \footnotetext{
E-mail: rrjgospo@cyf-kr.edu.pl enced vegetation index; yield. Science and Higher Education of the Republic of Poland.

Received for publication: 27 February 2019.

Revision received: 4 February 2020.

Accepted for publication: 19 February 2020.

CC Copyright: the Author(s), 2020

Licensee PAGEPress, Italy

Italian Journal of Agronomy 2020; 15:1418

doi:10.4081/ija.2020.1418
}

Correspondence: Janina Gospodarek, Department of Microbiology and Biomonitoring, University of Agriculture, 31-120 Krakow, Poland.

Key words: Stress conditions; plant-pest interaction; normalized differ-

Acknowledgements: scientific publication financed by the Ministry of

This article is distributed under the terms of the Creative Commons Attribution Noncommercial License (by-nc 4.0) which permits any noncommercial use, distribution, and reproduction in any medium, provided the original author(s) and source are credited.

\section{Introduction}

Normalized differenced vegetation index (NDVI) is an index allowing to assess very precisely the healthiness of a plant (Pinter et al., 2003; Onema et al., 2009). NDVI monitors the production of biomass, and the content of nutrients, as well as predicts the yield of plants (Klimek-Kopyra et al., 2018). It is also an indirect measure of photosynthetic activity. It assumes the values within the range from -1 (low) to +1 (high). NDVI is based on the differential reflection of radiation by green vegetation in two spectral wavebands, red (0.58-0.60 $\mu \mathrm{m})$ and near-infrared $(0.725-1.1 \mu \mathrm{m})$ (Mkhabela et al., 2011). Vegetative surfaces are characterized by high absorption of red radiation and low absorption of nearinfrared. Chlorophyll reflectance is about $20 \%$ in the red and $60 \%$ in the near-infrared, and the contrast between the crop's reflectance responses to both bands allows the quantification of the energy absorbed by chlorophyll, providing levels indicative of different vegetation surfaces (Rouse et al., 1973).

NDVI is also a common index of plant stress. The increase in the level of plant stress is coupled with the drop in the value of NDVI (Zhao et al., 2003). Recent studies showed the negative and significant correlation between NDVI and plant injury rating from sugarcane aphid Melanaphis sacchari (Zehntner) to grain sorghum (Sorghum bicolor (L.) Moench) (Elliot et al., 2015), as well as between NDVI and cotton aphid (Aphis gossypii Glover) on cotton (Gossypium spp.) plants (Guolong et al., 2016). The studies of this topic were mostly conducted under controlled conditions (with the determined levels of insect numbers, often very high) and they do not provide an unambiguous answer to the question of suitability of that index to assess the intensity of aphid occurrence depending on the cultivar, different level of fertilization, and various weather conditions. NDVI can also be indicative of the stress caused by the deficiency or excess of a nutrient as it was proven using nitrogen (Ma et al., 1996; Shanahan et al., 2003; Zhao et al., 2003; Solari et al., 2008) as well as water (Kizil et al., 2012; Severtson et al., 2016). Zhao et al. (2003), provoking nitrogen deficiency in maize (Zea mays L.) proved the reduced concentration of chlorophyll in leaves which subsequently caused the decrease in the value of NDVI. Only a few studies applying NDVI were conducted to monitor nutrients other than nitrogen (Ponzoni and Goncalves, 1999). Wiatrak (2013) found that the increased phosphorus fertilization in wheat (Triticum aestivum L.) cultivation caused the increase of NDVI.

Phosphorus is one of the basic nutrients necessary for the growth of plants. Its deficiency can lead to e.g. disturbance in protein synthesis, uptake and transfer of ions, therefore resulting in the growth inhibition of plants (Mengel and Kirkby, 1982). The fertilization needs for this element within the European Union (including the area of the experiment in this study) are estimated to be in the range of $0-50 \mathrm{~kg} \mathrm{P}_{2} \mathrm{O}_{5} \mathrm{ha}^{-1}$ according to the UK fertil- 
izer recommendation system, or $50-100 \mathrm{~kg} \mathrm{P}_{2} \mathrm{O}_{5} \mathrm{ha}^{-1}$ according to the Hungarian fertilizer recommendation system (Toth et al., 2014). The requirements of pea (Pisum sativum L.) in term of phosphorus are presently estimated to amount to $20-35 \mathrm{~kg} \mathrm{P}_{2} \mathrm{O}_{5}$ ha $^{-}$ 1 (Grzebisz, 2015). The earlier recommendations for the area of Poland were higher - Jasińska and Kotecki (2003) gave the range at $80-120 \mathrm{~kg} \mathrm{P}_{2} \mathrm{O}_{5} \mathrm{ha}^{-1}$ which results from environmental conditions. Increased fertilization with phosphorus increases the yield of pea (Dubey et al., 1999; Akhtar et al., 2003) and the size of the components in the yield structure, including: pod length, number of seeds per pod, and the mass of seeds (Gupta et al., 2000). Parsad et al. (1989) showed that applying high doses of phosphorus fertilizer $\left(120 \mathrm{~kg} \mathrm{P}_{2} \mathrm{O}_{5} \mathrm{ha}^{-1}\right)$ results in significant increase in biomass, yield of seeds, and the process of nodulation. The plants growing on soils deficient in phosphorus have often smaller leaf blades and shorter stems (Colomb et al., 2000). Phosphorus fertilization has also been shown to reduce an adverse effect resulting from the infestation of cowpea plants by aphids Aphis craccivora Koch. (Annan et al., 1997).

Aphids, feeding directly on cell sap, are particularly vulnerable to its composition (Butler et al., 2012). Either increase or decrease in the content of an element can result in far-reaching changes in the fertility or life span of aphids (Gospodarek, 2005; Gospodarek and Nadgórska, 2016; Rusin et al., 2017, 2018). The impact of phosphorus fertilization of host plant upon feeding of these insects is poorly documented and the data presented in various studies are discrepant (Butler et al., 2012). In their review, Waring and Cobb (1992) stated that phosphorus most often failed to affect sucking insects (48\% of studies analysed) or affect them positively (in approx. $38 \%$ of studies). Later studies, however, indicate that fertilisation with this element can also exert the effect in the form of limiting the density of sucking insects (Pitan et al., 2000) and lowering of damage (Asiwe, 2009). The existing discrepancies can derive from the species-specific features of a herbivore and a host plant, as well as from the level of fertilization applied. Moreover, as suggested by Jansson and Ekbom (2002) the relationship between the development of aphids and fertilization may not be of linear nature, and be also associated with the ratios between nutrients.

Pea aphid Acyrthosiphon pisum Harris is an important worldwide pest of many plant species of the Fabaceae family (Kulkarni, 2016). Among the host plants (pea, Pisum sativum L., broad bean, Vicia faba L., lucerne, Medicago sativa L., bean, Phaseolus vulgaris L., and red clover, Trifolium pratense L.), pea and broad bean are the most suitable for this pest - the rates of population increases on these plants are highest (Goławska, 2010), and they can differ depending on the cultivar (Soroka and Mackay, 1990a, 1990b). The effects of feeding by $A$. pisum is the reduction of yield resulting from sap sucking. The pest can also contribute to the spread of viral diseases (Saucke et al., 2009).

NDVI index so far was used to asses both infestation of plants by aphids and the impact of nutrient deficiencies on the condition of plants, however, these factors were analyzed separately. In the field conditions we often have to deal with the impact of many different biotic and abiotic factors, which together (in addition interacting with each other) are responsible for the final condition of the plant. It would be interesting to get an answer whether NDVI will also be useful in assessing the infestation of aphids and yield when several factors act together, i.e. different phosphorus fertilization, cultivar and meteorological conditions. Different cultivars may differ in their resistance to aphids, hence the number of aphids may vary on them, phosphate fertilization also indirectly affects sucking pests and may increase or decrease their numbers. At the same time, both fertilization and cultivars can affect the value of the NDVI index. Can NDVI be used to assess the intensity of aphids and to predict the yield when interacting with these several factors?

The objectives of the presented study were to find firstly the effect of the increasing doses of phosphorus fertilization $(0,70$, and $140 \mathrm{~kg} \mathrm{P}_{2} \mathrm{O}_{5} \mathrm{ha}^{-1}$ ) on the pea aphid (Acyrthosiphon pisum Harris) occurrence on various cultivars of pea (Pisum sativum L.) (Tarchalska, Batuta, Model, Protecta, Mecenas and Tinker) and secondly - the suitability of NDVI index to the evaluation of pea plant infestation by aphids and expected yield of pea under diverse levels of phosphorus fertilization.

\section{Materials and methods}

\section{Experimental design}

The field experiments were conducted in 2013-2015 within the Experimental Station of the University of Agriculture, at Prusy near Cracow (47॰24'N lat., $7^{\circ} 19^{\prime} \mathrm{E}$ long., $300 \mathrm{~m}$ a.s.1.). The experiment was set up by the method of randomized blocks, in four repetitions. The area of each experimental plot was $15 \mathrm{~m}^{2}$. The distances between plots were $1.5 \mathrm{~m}$ and were maintained as bare soil by mechanical cultivation. Wheat was the pre-crop for pea. Rapeseed was grown before wheat. Wheat was harvested in August, than the soil was harrowing twice and catch crop (Sinapsis alba) was sown. In October the catch crop was removed by ploughing. In spring the soil was prepared for pea sowing. Prior to the sowing of seeds, mineral fertilizers were applied, and the soil was seed-bed prepared by harrowing and cultivating. Mineral fertilizing was applied using ammonium nitrate (34\%) in a $30 \mathrm{~kg} \mathrm{~N}$ $\mathrm{ha}^{-1}$ dose, potassium salt $(60 \%)$ in a $100 \mathrm{~kg} \mathrm{~K}_{2} \mathrm{O} \mathrm{ha}^{-1}$ dose, and granulated triple superphosphate (46\%) in $70 \mathrm{~kg} \mathrm{P}_{2} \mathrm{O}_{5}$ ha $^{-1}$ and 140 $\mathrm{kg} \mathrm{P}_{2} \mathrm{O}_{5} \mathrm{ha}^{-1}$ doses. According to polish guidelines of pea cultivation, the optimal dose of $\mathrm{P}_{2} \mathrm{O}_{5}$ is $70 \mathrm{~kg} \mathrm{ha}^{-1}$ (HR Smolice seed company, https://www.hrsmolice.pl/pl/straczkowe/groch-siewny/29podstawowe-zalecenia-agrotechniczne -last accessed: 04.02.2020). Observed progress in plant breeding for pea needs to assess the pea yielding potential based on phosphorus requirements. Two extreme doses ( 0 and $140 \mathrm{~kg} \mathrm{P}_{2} \mathrm{O}_{5}$ ha $\left.^{-1}\right)$ were selected to verify the production potential and healthiness of new pea varieties. In subsequent years, sowing was done in the third ten days of March, using a plot drill with sowing distance of $15 \mathrm{~cm}$. During pea cultivation, chemical weed control procedures were applied twice. The first procedure was conducted in the first ten days of April, applying Linurex 500 SC (linuron - $500 \mathrm{~g}$ per litre of preparation, Adama Polska Sp. $\mathrm{z}$ o.o.) herbicide in $1.251 \mathrm{ha}^{-1}$ dose (625 g active ingredient (AI) $\left.\mathrm{ha}^{-1}\right)$. The subsequent procedure was performed in the third ten days of April, using Basagran 480 SL (bentazone - $480 \mathrm{~g}$ per litre of preparation, BASF SE) herbicide in $31 \mathrm{ha}^{-1}$ dose $\left(1.44 \mathrm{~kg} \mathrm{AI} \mathrm{kg}^{-1}\right)$.

The soil on the experimental field was Haplic Phaeozem (finegrained, with the ratio of sand $:$ silt : clay $=14: 39: 47$ respectively). It had an average content of phosphorus $\left(9.4 \mathrm{mg} 100 \mathrm{~g}^{-1}\right.$ of

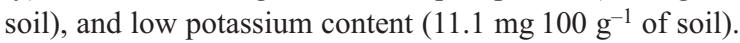

The experiment involved six cultivars of pea, cultivated in three series differing in the level of fertilization: without phosphorus fertilization (0); with the dose of $70 \mathrm{~kg} \mathrm{P}_{2} \mathrm{O}_{5} \mathrm{ha}^{-1}$ (70), and with the dose of $140 \mathrm{~kg} \mathrm{P}_{2} \mathrm{O}_{5}$ ha $^{-1}$ (140). The experiment included two forage cultivars: Model and Tinker, as well as four, multipurpose cultivars: Mecenas, Tarchalska, Batuta, and Protecta, Tinker was of Austrian origin, whereas Protecta - of Czech origin. 


\section{The occurrence of aphids on plants}

Observations were conducted from the date when the first winged migrants were noted on plants, until the end of the occurrence of $A$. pisum, every 5-7 days, on 30 randomly selected, marked pea stems in each plot. Observations were carried out in each season of the study, usually eight times, between the beginning of June till the end of July. The number of particular morphs (wingless females, winged females, and larvae) was determined. The presented results are means from all observation dates in a given study season. In view of data from publications, the sizes of pea plots $\left(15 \mathrm{~m}^{2}\right)$ were sufficient to evaluate the level of the infestation of plants by aphids (Bieri et al., 1983, Saucke et al., 2009).

\section{NDVI measurements}

NDVI measurements were taken with the GreenSeeker ${ }^{\mathrm{TM}}$ Handheld Optical Sensor Unit (NTech Industries, Inc., USA) in the central rows of all plots. The distance between canopy and device was $60 \mathrm{~cm}$. Each plot was measured 5 times. Measurements of the NDVI were carried out 3 times at each characteristic growth stages: budding (BBCH 51-55), flowering phase (BBCH 60-69), and development of fruits - flat-pod phase (BBCH 71-75). The presented results of NDVI are averages from the measurements taken at three dates.

\section{Ordinal regression model}

The process of selecting predictors for the location component defined in regression model as agronomic factors, was taking into consideration in both the theoretical and empirical sides. Because the discrimination o potential predictor variables that are expected to influence seed yield was the aim of the studies, the analysis started off by including all the variables involved and considered influential. Stepwise variables not helpful in the model such as plant parameters, were removed from the analysis and the model was re-estimated, to get significant differences of model components. Qualitative variables (year, cultivar and fertilization) were entered as the factors in the model, and, on the other hand, quantitative variables (NDVI and aphids) were entered as covariates in the ordinal regression model. The Wald test was used to determine whether a certain predictor variable is significant or not.

The ordinal regression model was used to predict ordinal dependent variables. The outcome variable was seed yield, with four ordinal levels, which was the most suited combination for this model according to Klimek-Kopyra et al. (2017) methodology: <3; $3-3.6 ; 3.6-4.5 ;>4.5$. The ordinal regression was used to determine potential predictor variables (agronomical - fertilization, cultivar type, and plant - NDVI, and environmental - aphids) that are expected to influence seed yield. The variable year was entered into the model as the scale component. This constituent function is the modification of the model to account for differences in the variability of the independent variables (Klimek-Kopyra et al., 2017). Positive value "+" of the estimated variables such as cultivars (Batuta, Mecenas, Tarchalska) or NDVI index suggest a positive relationship between these predictors and the dependent variable. As the estimated variables obtained positive value, so does exist the high probability of yield being in one of the higher category. Conversely, negative estimates (fertilization and aphids) indicate an inverse relationship. An increase in the variable fertilization predisposes a pea seed to be classified to the lower outcome variable categories.

Fitting information (Table 1) shows that the use of predictor variables significantly improves the model's ability to adequately predict seed yield. According to Mccullagh and Nelder (1989), the difference between -2 times the log-likelihood for the interceptonly model and for the final model can be interpreted as chi-square statistics. The significant chi-square statistic indicates that the final ordinal regression model gives better predictions than those based on marginal probabilities for the outcome variable categories. This could be interpreted as a meaningful impact of the variables considered in the final model on seed yield. The overall assessment of goodness of fit of the final model was done by Nagelkerke pseudo-R-square.

\section{Statistical analysis}

Statistical calculations were performed with the use of Statistica 12.0 PL software package (StatSoft). The data analyses were preceded by normality test (Shapiro-Wilk with Lilliefors correction), and by Levene's test of equality of variances. The significance of differences between means was studied by one- two- and three- way analyses of variance. The means were differentiated by LSD Fisher test at $\mathrm{P}<0.05$. In order to obtain information about the relationship between the number of aphids and the value of NDVI index, Pearson's correlation coefficients were calculated by comparing the mean values of NDVI from a given measurement for a given plot, with the mean number of aphids per stem in the period preceding the NDVI measurement on the same plot.

\section{Results}

\section{Weather conditions}

The mean temperature and the sum of precipitation aimed to find the course of weather changes were obtained from an automatic meteorological station in Prusy, belonging to Department of Crop Production, University of Agriculture in Krakow. The duration of measurements covered the period of pea growing i.e. from April to July. In the years of study, weather conditions were variable (Table 2). In 2013, May and June were relatively humid with respect to the requirements of pea. The year 2014 turned out to be the most humid of all in the three years of study, due to heavy rains in May and July, when the respective total precipitation amounted to 107.5 and $183.2 \mathrm{~mm}$. In the subsequent year (2015), with very humid month of May, the recorded total precipitation, measured for the whole growing season, was lower.

The months when atmospheric droughts occurred were identified on the basis of the value of hydrothermal index $\mathrm{K} \leq 1.0$ (Cherszkowicz, 1971). The conducted observation implies that in all years of study, the extreme drought $(\mathrm{K} \leq 0.4)$ occurred in the month of April, and in June of 2014 and 2015, and also in July in 2013 and 2015 . May was usually dry $(0.7<\mathrm{K} \leq 1.0)$. The hydrothermal index $\mathrm{K}$ is the most credible in identifying the atmospheric drought during the periods when the average daily temperatures are higher than $10^{\circ} \mathrm{C}$ (Cherszkowicz, 1971).

Table 1. Model fitting information.

Model $-2 \mathrm{Log}$ likelihood Chi-square if Significance

\begin{tabular}{lllll} 
Intercept only & 428.110 & & & \\
Final model & 358.646 & 69.464 & 11 & 0.000 \\
\hline
\end{tabular}




\section{The occurrence of aphids on plants}

All analysed factors i.e. the level of phosphorus fertilization, cultivar, and the study season had significant effects on the mean numbers of A. pisum (Table 3). Taking into account the particular seasons of studies, the aphids occurred most abundantly in 2015 (Figure 1A). Their mean number per stem was more than four times higher than in 2013 and 2014. The significant differences between cultivars were seen exclusively in the 2015 season. The least colonised by aphids were Protecta and Tinker cultivars, the most intensively - Model cultivar. Considering the levels of fertilization, the results of the studies showed that the lowest number of aphids was noted on plants not treated with phosphorus fertilization (except Mecenas cultivar) (Figure 1B). The analysis of inter-
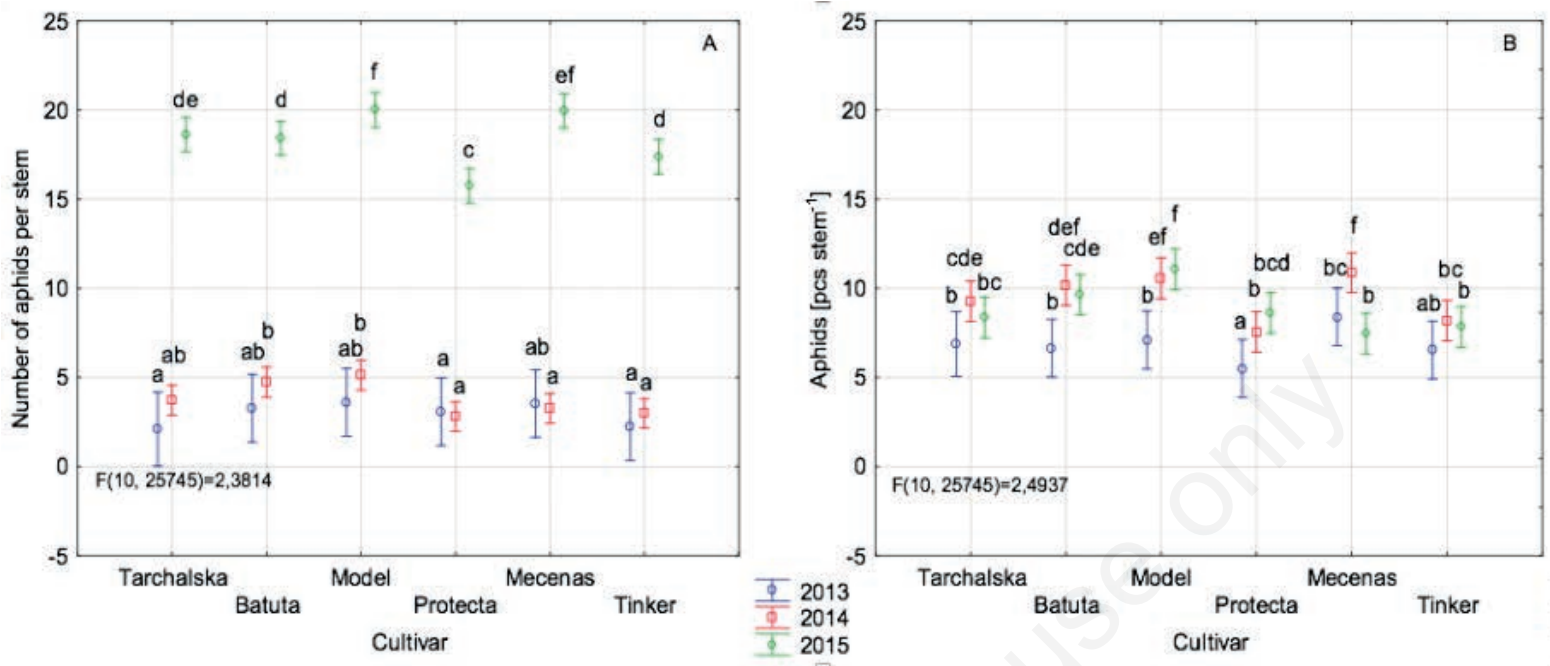

Figure 1. Mean numbers of aphids Acyrthosiphon pisum Harris on different pea cultivars cultivated at increasing doses of phosphorus fertilization $\left(0,70\right.$, and $\left.140 \mathrm{~kg} \mathrm{P}_{2} \mathrm{O}_{5} \mathrm{ha}^{-1}\right)$ in the years 2013-2015. Two-way analysis, factors: cultivar $\times$ year (A); cultivar $\times$ fertilization (B). Vertical bars denote $\mathbf{0 . 9 5}$ confidence intervals. Means followed by the same letters are not significantly different according to the least significant difference test $(\mathbf{P}<0.05)$.

Table 2. Weather conditions (average daily temperatures and sum of rainfall, data collected from the weather station located in the Experimental Station in Prusy).

\begin{tabular}{|c|c|c|c|c|c|}
\hline & Month & 2013 & 2014 & 2015 & Water requirements of pea \\
\hline Temperature $\left({ }^{\circ} \mathrm{C}\right)$ & $\begin{array}{c}\text { April } \\
\text { May } \\
\text { June } \\
\text { July }\end{array}$ & $\begin{array}{c}8.8 \\
14.2 \\
17.6 \\
19.2\end{array}$ & $\begin{array}{l}11.3 \\
14.3 \\
16.7 \\
20.4\end{array}$ & $\begin{array}{c}9.1 \\
13.3 \\
17.5 \\
20.6\end{array}$ & $\begin{array}{l}- \\
- \\
-\end{array}$ \\
\hline Rainfall (mm) & $\begin{array}{c}\text { April } \\
\text { May } \\
\text { June } \\
\text { July }\end{array}$ & $\begin{array}{c}20.1 \\
98.8 \\
213.1 \\
27.2\end{array}$ & $\begin{array}{c}43.0 \\
107.5 \\
80.1 \\
183.2\end{array}$ & $\begin{array}{c}19.4 \\
101.6 \\
52.6 \\
71.8\end{array}$ & $\begin{array}{l}40 \\
65 \\
70 \\
45\end{array}$ \\
\hline$K^{a}$ & $\begin{array}{c}\text { April } \\
\text { May } \\
\text { June } \\
\text { July }\end{array}$ & $\begin{array}{l}0.228 \\
0.696 \\
1.211 \\
0.142 \\
\end{array}$ & $\begin{array}{l}0.381 \\
0.753 \\
0.480 \\
0.897\end{array}$ & $\begin{array}{l}0.213 \\
0.765 \\
0.300 \\
0.348\end{array}$ & $\begin{array}{l}- \\
- \\
- \\
-\end{array}$ \\
\hline
\end{tabular}

${ }_{\mathrm{a}} \mathrm{K}=10 \mathrm{P} / \Sigma \mathrm{t}$, where: $\mathrm{P}$ - total monthly rainfall (mm), $\Sigma \mathrm{t}$ - monthly sum of average temperatures. $\mathrm{K} \leq 0.4$ - extremely dry; $0.4<\mathrm{K} \leq 0.7$ - very dry; $0.7<\mathrm{K} \leq 1.0$ - dry; $1.0<\mathrm{K} \leq 1.3$ - quite dry; $1.3<\mathrm{K} \leq 1.6$ - optimum (Cherszkowicz, 1971 ).

Table 3. Results of the statistical analysis of the number of aphids Acyrthosiphon pisum Harris.

\begin{tabular}{lccccc}
\hline Effects & SS & df & MS & F & p \\
Cultivar & 10,459 & 5 & 2092 & 5.336 & 0.0001 \\
Fertilization & 15,304 & 2 & 7652 & 19.521 & 0.0000 \\
\hline Year & $1,292,808$ & 2 & 646,404 & 1649.029 & 0.0000 \\
Fertilization $\times$ year & 28,139 & 4 & 7035 & 17.946 & 2.381 \\
\hline Cultivar $\times$ year & 9335 & 10 & 933 & 2.494 & 0.0000 \\
Cultivar $\times$ fertilization & 9775 & 10 & 1243 & 3.170 & 0.0055 \\
\hline Cultivar $\times$ fertilization $\times$ year & 24,850 & 20 & & 0.0000 \\
\hline
\end{tabular}

SS, sum of squares; df, degrees of freedom; MS, mean squares; F, Fisher; Snedecor's test; p, probability level. 
action between the fertilization and the pea cultivar showed a significant increase in the number of aphids under the effect of phosphorus fertilization, independently of dose, in Batuta, Model, and Protecta cultivars. In the case of Tarchalska and Mecenas cultivars, significantly higher number of aphids was found only when the phosphorus dose of $70 \mathrm{~kg} \mathrm{ha}^{-1}$ was applied. In Tinker cultivar, none of the doses used resulted in statistically significant differences.

The analysis also showed significant effects of fertilization level and the study season upon the number of winged forms of $A$. pisum aphid, whereas the pea cultivar did not affect significantly this parameter (Table 4). The significant interactions of all three analysed factors, i.e. the cultivar, level of fertilization and year of study were also noted. Similarly as in the case of total number of aphids, the statistically significant differences between cultivars were found only in 2015 season (Figure 2A). In the cases of Tarchalska and Mecenas cultivars the tendency was found, matching that revealed for the total number of aphids i.e. the highest number of winged aphids when the phosphorus fertilization was applied in the dose of $70 \mathrm{~kg}$ $\mathrm{ha}^{-1}$ (Figure 2B). In Batuta, Protecta, and Tinker cultivars, however, the highest number of winged females was found with the highest dose of phosphorus fertilization.

\section{NDVI as a detector of plants status in the conditions of varied levels of phosphorus fertilization}

On the basis of statistical analysis, it was found that the value of NDVI index depended significantly on the course of weather conditions in particular years, and on the selection of cultivars (Table 5). The separate analysis of the years of study also revealed the significant effect of phosphorus fertilization, but only in 2015 (Table 6).

The value of NDVI was significantly higher in 2014, and lower in 2013 (Figure 3A). Among the cultivars compared in the study, Protecta cultivar had the highest value of the parameter $(0.61)$ whereas Tinker cultivar - the lowest (0.55) (Figure 3B). On the basis of two-factor analysis conducted separately for years, the significant effect of interaction of the selection of cultivar and the level of phosphorus fertilization was found. The highest value of the index was obtained for Protecta cultivar in control condition (Figure 4A). In 2015, low quantity of precipitation was recorded (Table 2) which resulted in the increase of NDVI value along the increase of phosphorus fertilization. Applying the high dose of phosphorus resulted in the significant increase of NDVI in cultivar with normal leaf arrangement - Protecta. Different results were obtained for the cultivar Tinker in afila type (Figures 4B and 5).
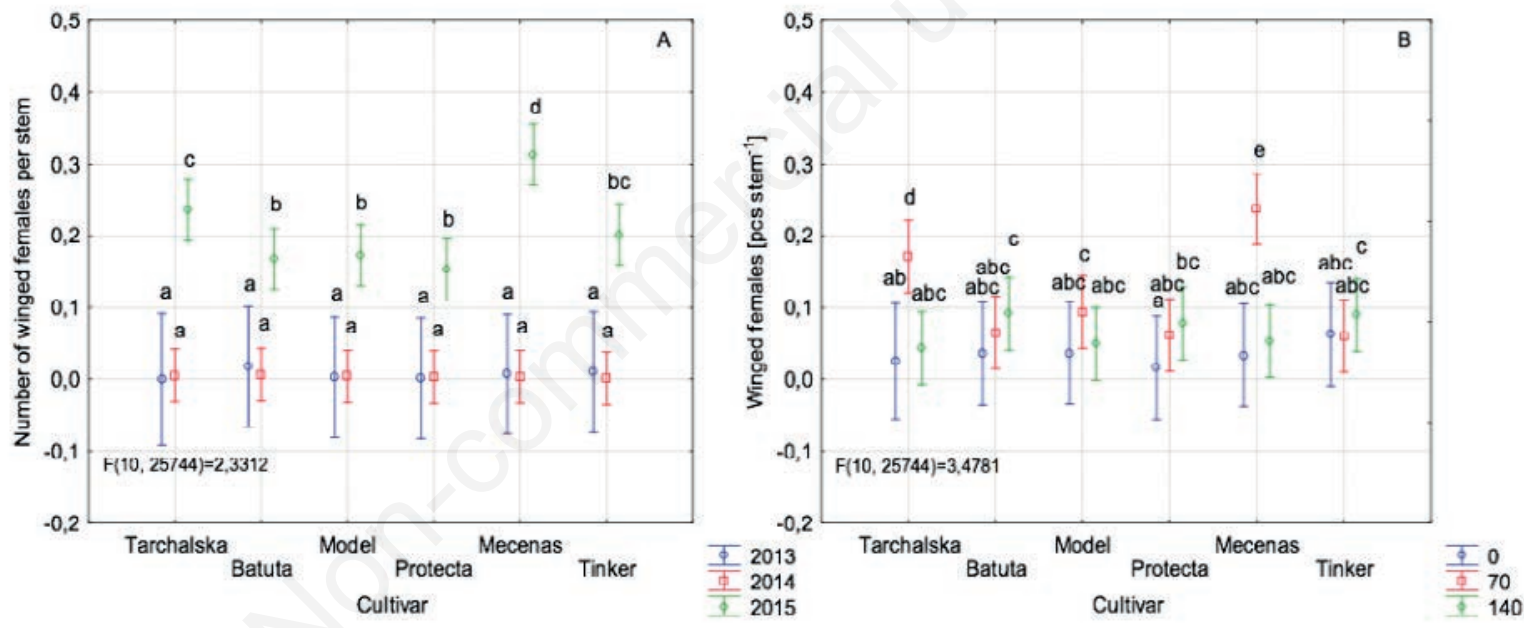

Figure 2. Mean numbers of winged females of Acyrthosiphon pisum Harris on different pea cultivars cultivated at increasing doses of phosphorus fertilization $\left(0,70\right.$, and $\left.140 \mathrm{~kg} \mathrm{P}_{2} \mathrm{O}_{5} \mathrm{ha}^{-1}\right)$ in the years 2013-2015. Two-way analysis, factors: cultivar $\mathrm{x}$ year (A); cultivar $\times$ fertilization (B). Vertical bars denote 0.95 confidence intervals. Means followed by the same letters are not significantly different according to the least significant difference test $(P<0.05)$.

Table 4. Results of the statistical analysis of the number of winged females of Acyrthosiphon pisum Harris.

\begin{tabular}{lccccc} 
Effects & SS & df & MS & P \\
Cultivar & 5.07 & 5 & 1.0145 & 1.3254 & 0.2499 \\
Fertilization & 16.23 & 2 & 8.1160 & 10.6034 & 0.0000 \\
\hline Year & 245.63 & 2 & 122.8139 & 160.4535 & 0.0000 \\
Fertilization $\times$ year & 58.44 & 4 & 14.6102 & 19.0879 & 0.0000 \\
\hline Cultivar $\times$ year & 17.84 & 10 & 1.7843 & 2.3312 & 0.0097 \\
Cultivar $\times$ fertilization & 26.62 & 10 & 2.6622 & 3.4781 & 0.0001 \\
\hline Cultivar $\times$ fertilization $\times$ year & 77.14 & 20 & 3.8572 & 5.0393 & 0.0000 \\
\hline
\end{tabular}

SS, sum of squares; df, degrees of freedom; MS, mean squares; F, Fisher; Snedecor's test; p, probability level. 


\section{Relationship between the number of aphids and NDVI}

The correlation analysis between the NDVI value and the mean number of $A$. pisum aphids showed the very high variability depending on the season of the year when it was carried out (Table 7). In 2013 season, the negative correlation between these parameters (statistically significant in most cases) was noted for all cultivars and levels of fertilization. In 2014, in the majority of cases the correlations lacked statistical significance whereas in 2015 the correlation coefficient generally assumed positive values (statistically significant in many cases).

\section{Seed yield}

All three factors (cultivar, fertilization, and year) had significant effects on seed yield (Table 8). Seed yield was higher in 2014 and 2015 than in 2013. The highest seed yield achieved edible cul- tivar Tarchalska whereas, the fodder cultivar Model gained the lowest yield. The use of phosphorus fertilization had a relevant effect on the seed mass but significantly influenced seed yield with the highest dose of phosphorus application (Figure 6 A-C).

\section{Model interpretation}

The parameter estimates for the final model are shown in Table 9. According to the ordinal regression model results, the qualitative variables such as fertilization and cultivars, and, quantitative variable such as NDVI index, are meaningful predictors of seed yield. The seed yield was significantly higher in selected cultivars: Batuta, Mecenas, Tarchalska. Phosphorus fertilization was a meaningful predictor of seed yield. Estimates of parameters for the fertilization factor (in lower P doses) indicated significant but negative relationship between these predictor and higher seed yield categories of the dependent variable.
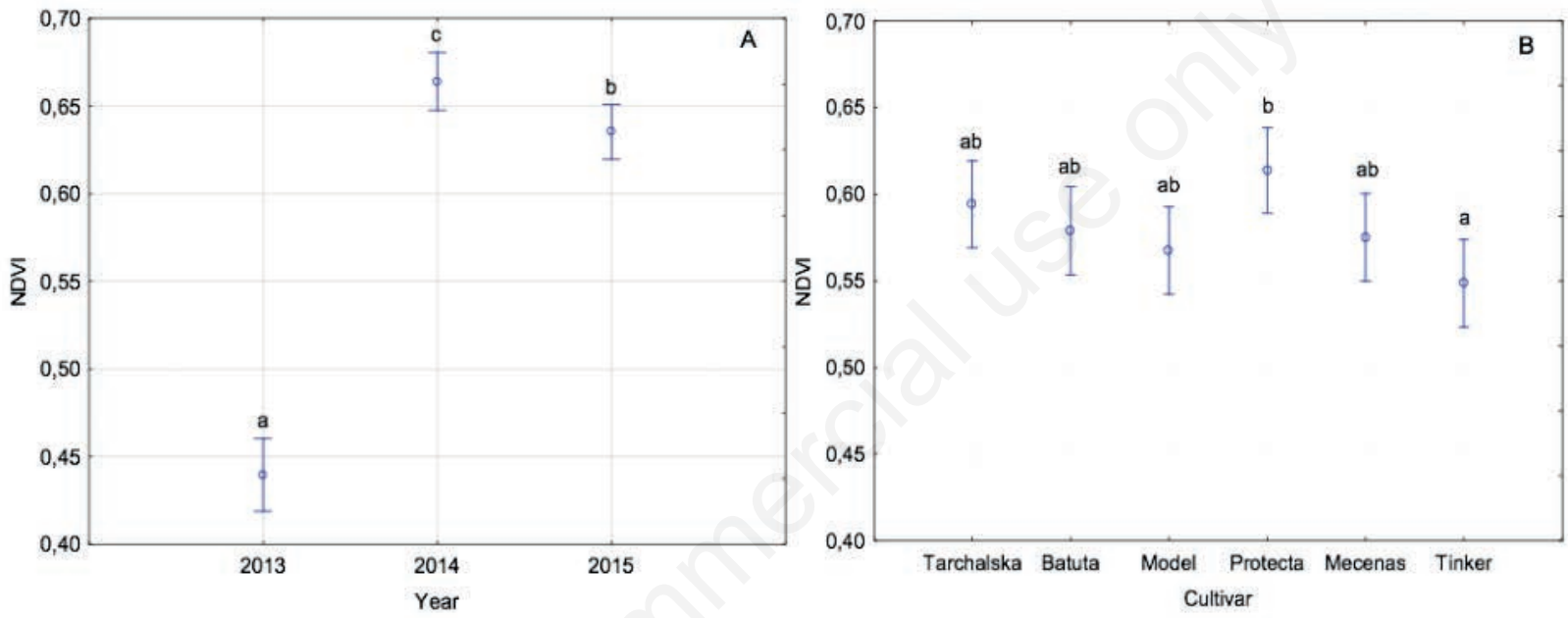

Figure 3. Mean value of NDVI index for different pea cultivars cultivated in the years 2013-2015. One-way analysis, factor: year (A); cultivar (B). Vertical bars denote $\mathbf{0 . 9 5}$ confidence intervals. Means followed by the same letters are not significantly different according to the least significant difference test $(P<0.05)$.

Table 5. Results of the statistical analysis of NDVI index mean in years 2013-2015.

\begin{tabular}{lccccc}
\hline Effects & SS & df & MS & F \\
Cultivar & 123.121 & 2 & 61.560 & 153.01 & 0.0000 \\
Fertilization & 0.264 & 2 & 0.132 & 0.33 & 0.7199 \\
\hline Year & 6.220 & 5 & 1.244 & 3.09 & 0.0086 \\
Fertilization $\times$ year & 3.247 & 10 & 0.325 & 0.51 & 0.6219 \\
\hline Cultivar $\times$ year & 5.631 & 10 & 0.620 & 1.40 & 0.1733 \\
Cultivar $\times$ fertilization & 2.479 & 4 & 0.422 & 1.05 & 0.1874 \\
\hline Cultivar $\times$ fertilization $\times$ year & 8.441 & 20 & & 0.3984 \\
\hline
\end{tabular}

SS, sum of squares; df, degrees of freedom; MS, mean squares; F, Fisher; Snedecor's test; p, probability level.

Table 6. Results of the statistical analysis of NDVI index in particular years $(2013,2014,2015)$ separately.

\begin{tabular}{lcccccc} 
& SS & df & 2013 & 2014 & 2015 \\
P-value & & 0.253 & 0.0000 \\
Cultivar & & & & 0.000 & 0.326 & 0.0228 \\
Fertilization & 3.028 & 5 & 0.118 & 0.411 & 0.0000 \\
\hline Cultivar $\times$ fertilization & 0.111 & 2 & 0.026 & & \\
\hline
\end{tabular}

SS, sum of squares; df, degrees of freedom; MS, mean squares; F, Fisher; Snedecor's test; p, probability level. 

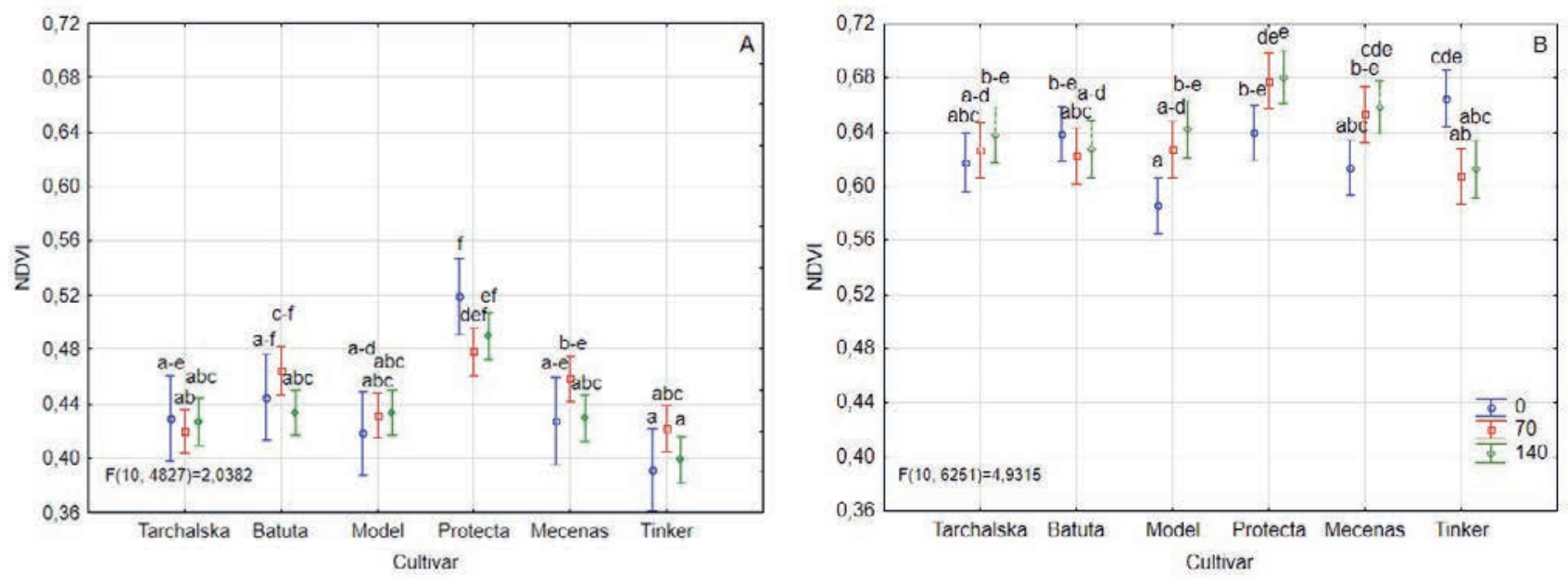

Figure 4. Mean value of NDVI index for different pea cultivars cultivated at increasing doses of phosphorus fertilization (0, 70, and 140 $\mathrm{kg} \mathrm{P}_{2} \mathrm{O}_{5} \mathrm{ha}^{-1}$ ) in the years 2013 (A) and 2015 (B). Two-way analysis, factors: cultivar $\times$ fertilization. Vertical bars denote 0.95 confidence intervals. Means followed by the same letters are not significantly different according to the least significant difference test $(P<0.05)$.
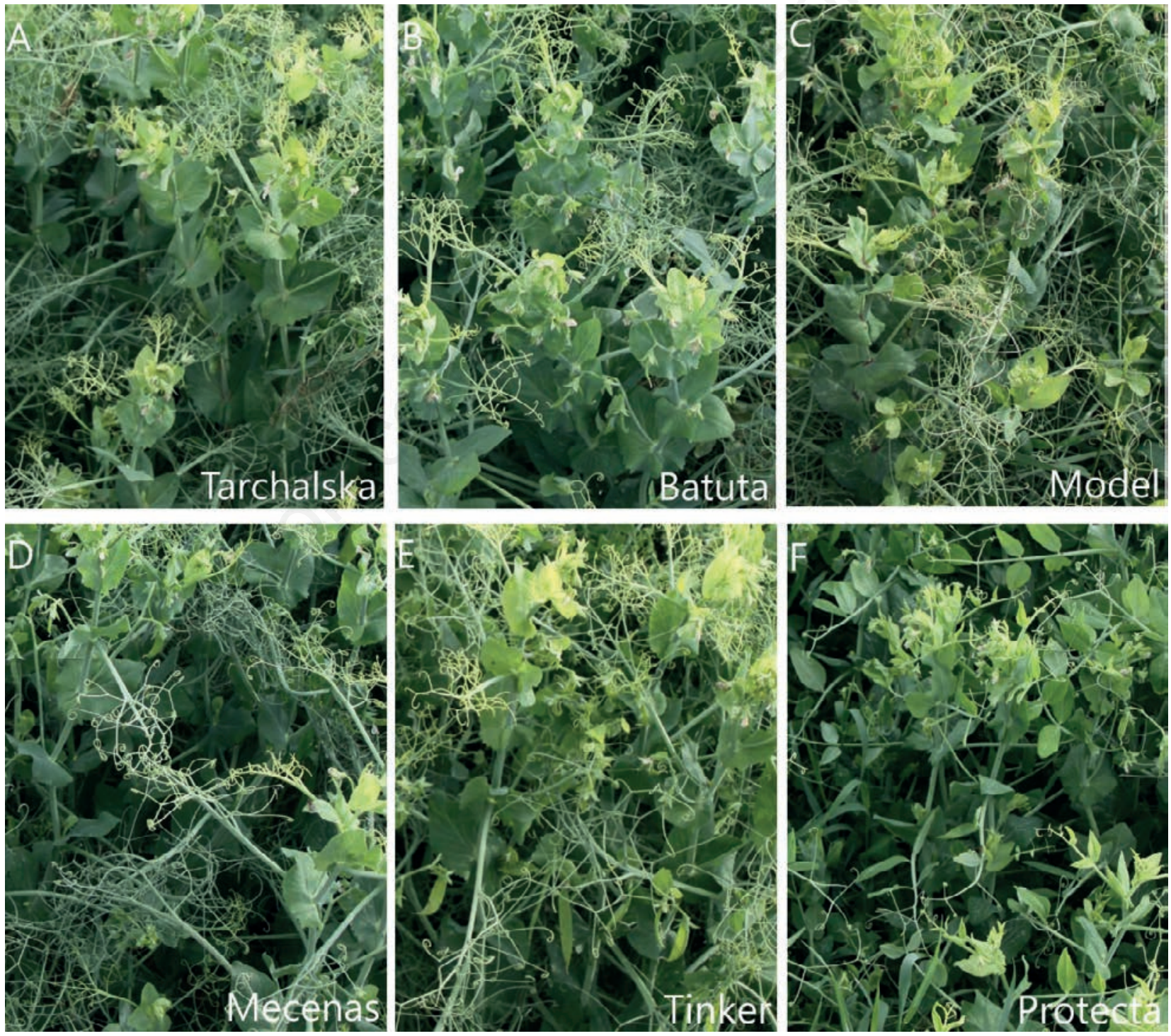

Figure 5. Leaves of the different cultivars used in the study. 
Table 7. Pearson correlation coefficients between number of aphids and NDVI.

\begin{tabular}{|c|c|c|c|c|}
\hline Cultivar & Fertilization & 2013 & 2014 & 2015 \\
\hline & $\begin{array}{c}\text { Without division into groups } \\
0 \\
70 \\
140\end{array}$ & $\begin{array}{l}-0.655^{* *} \\
-0.542 \\
-0.561^{* *} \\
-0.737^{* *}\end{array}$ & $\begin{array}{l}0.034 \\
0.316 \\
-0.019 \\
-0.164\end{array}$ & $\begin{array}{c}0.422^{* *} \\
0.495^{*} \\
0.357^{*} \\
0.615^{* *}\end{array}$ \\
\hline Tarchalska & $\begin{array}{c}0 \\
70 \\
140 \\
\text { Irrespectively }\end{array}$ & $\begin{array}{l}-0.752^{*} \\
-0.952^{* *} \\
-0.875^{*} \\
-0.8315^{* *}\end{array}$ & $\begin{array}{l}0.848^{*} \\
0.634 \\
0.254 \\
0.332\end{array}$ & $\begin{array}{c}0.843^{*} \\
0.495 \\
0.900^{*} \\
0.599^{* *}\end{array}$ \\
\hline Batuta & $\begin{array}{c}0 \\
70 \\
140 \\
\text { Irrespectively }\end{array}$ & $\begin{array}{l}-0.5765 \\
-0.3745 \\
-0.8745^{*} \\
-0.707^{* *}\end{array}$ & $\begin{array}{l}-0.179 \\
-0.653 \\
-0.527 \\
-0.450\end{array}$ & $\begin{array}{l}0.424 \\
0.311 \\
0.503 \\
0.346\end{array}$ \\
\hline Model & $\begin{array}{c}0 \\
70 \\
140 \\
\text { Irrespectively }\end{array}$ & $\begin{array}{c}-0.769 \\
-0.811 \\
-0.899^{*} \\
-0.816^{* *}\end{array}$ & $\begin{array}{c}0.231 \\
0.185 \\
-0.168 \\
-0.102\end{array}$ & $\begin{array}{l}0.636 \\
0.550 \\
0.712 \\
0.553^{*}\end{array}$ \\
\hline Protecta & $\begin{array}{c}0 \\
70 \\
140 \\
\text { Irrespectively }\end{array}$ & $\begin{array}{l}-0.654^{*} \\
-0.833^{*} \\
-0.867^{*} \\
-0.784^{* *}\end{array}$ & $\begin{array}{c}-0.461 \\
-0.271 \\
0.302 \\
0.0371\end{array}$ & $\begin{array}{l}0.832^{*} \\
0.776 \\
0.946^{* *} \\
0.625^{* *}\end{array}$ \\
\hline Mecenas & $\begin{array}{c}0 \\
70 \\
140 \\
\text { Irrespectively }\end{array}$ & $\begin{array}{c}-0.757^{*} \\
-0.649 \\
-0.824^{*} \\
-0.743^{* *}\end{array}$ & $\begin{array}{c}0.437 \\
0.010 \\
-0.045 \\
0.160\end{array}$ & $\begin{array}{l}0.854^{*} \\
0.457 \\
0.593 \\
0.489^{*}\end{array}$ \\
\hline Tinker & $\begin{array}{c}0 \\
70 \\
140 \\
\text { Irrespectively }\end{array}$ & $\begin{array}{l}-0.655 \\
-0.605 \\
-0.757 \\
-0.635^{*} \\
\end{array}$ & $\begin{array}{c}-0.019 \\
0.384 \\
-0.435 \\
-0.004 \\
\end{array}$ & $\begin{array}{c}-0.065 \\
0.197 \\
0.950^{* *} \\
0.188 \\
\end{array}$ \\
\hline
\end{tabular}

* Significant at $\mathrm{P}<0.05 ; * *$ significant at $\mathrm{P}<0.01$.

Table 8. Results of the statistical analysis of the yield.

\begin{tabular}{|c|c|c|c|c|c|}
\hline Effects & SS & df & MS & $\mathrm{F}$ & p \\
\hline Cultivar & 11.187 & 5 & 2.237 & 2.590 & 0.0305 \\
\hline Fertilization & 5.965 & 2 & 2.982 & 3.453 & 0.0356 \\
\hline Year & 8.460 & 2 & 4.230 & 4.897 & 0.0094 \\
\hline Fertilization $\times$ year & 3.844 & 10 & 0.384 & 0.445 & 0.9204 \\
\hline Cultivar $\times$ year & 12.036 & 10 & 1.204 & 1.393 & 0.1949 \\
\hline Cultivar $\times$ fertilization & 6.765 & 4 & 1.691 & 1.958 & 0.1071 \\
\hline Cultivar $\times$ fertilization $\times$ year & 14.094 & 20 & 0.705 & 0.816 & 0.6891 \\
\hline
\end{tabular}

SS, sum of squares; df, degrees of freedom; MS, mean squares; F, Fisher; Snedecor's test; p, probability level.

Table 9. Statistical evaluation of considered factors (ordinal regression model) for seed yield categories.

\begin{tabular}{|c|c|c|c|c|c|c|c|c|}
\hline $\begin{array}{l}\text { Model } \\
\text { component }\end{array}$ & Variable level & Estimate & $\begin{array}{c}\text { Standard } \\
\text { error }\end{array}$ & Wald & df & Significance & $\begin{array}{l}95 \% \text { Confide } \\
\text { Lower bound }\end{array}$ & $\begin{array}{l}\text { nce interval } \\
\text { Upper bound }\end{array}$ \\
\hline \multirow[t]{3}{*}{ Threshold } & Seed yield [1] & 1.699 & 0.591 & 8.254 & 1 & 0.004 & 0.540 & 2.858 \\
\hline & Seed yield [2] & 2.595 & 0.690 & 14.135 & 1 & 0.000 & 1.242 & 3.948 \\
\hline & Seed yield [3] & 3.996 & 0.869 & 21.165 & 1 & 0.000 & 2.294 & 5.698 \\
\hline \multirow[t]{11}{*}{ Location } & [cv = Batuta] & 0.818 & 0.350 & 5.455 & 1 & 0.020 & 0.132 & 1.505 \\
\hline & {$[\mathrm{cv}=$ Mecenas $]$} & 0.724 & 0.345 & 4.406 & 1 & 0.036 & 0.048 & 1.401 \\
\hline & {$[\mathrm{cv}=$ Model $]$} & -0.280 & 0.352 & 0.634 & 1 & 0.426 & -0.971 & 0.410 \\
\hline & {$[\mathrm{cv}=$ Protecta $]$} & -0.229 & 0.340 & 0.454 & 1 & 0.501 & -0.896 & 0.438 \\
\hline & [cv= Tarchalska $]$ & 0.899 & 0.358 & 6.308 & 1 & 0.012 & 0.197 & 1.600 \\
\hline & [cv= Tinker $]$ & 0.00 & - & - & 0 & - & - & - \\
\hline & {$[$ Fertilization $=0$ ] } & -1.363 & 0.332 & 16.829 & 1 & 0.000 & -2.015 & -0.712 \\
\hline & [Fertilization=70] & -0.488 & 0.230 & 4.490 & 1 & 0.034 & -0.939 & -0.037 \\
\hline & [Fertilization $=140$ ] & 0.00 & - & - & 0 & - & - & - \\
\hline & [Aphids] & -0.030 & 0.017 & 2.926 & 1 & 0.087 & -0.064 & 0.004 \\
\hline & [NDVI] & 4.770 & 1.254 & 14.469 & 1 & 0.000 & 2.312 & 7.228 \\
\hline \multirow[t]{3}{*}{ Scale } & [Year=2013] & -0.909 & 0.253 & 12.908 & 1 & 0.000 & -1.405 & -0.413 \\
\hline & {$[$ Year $=2014]$} & -0.324 & 0.237 & 1.881 & 1 & 0.170 & -0.788 & 0.139 \\
\hline & [Year=2015] & 0.00 & - & - & 0 & - & - & - \\
\hline
\end{tabular}


Negative value of estimated parameters for lower doses of phosphorus indicated the direction of changes relationship between variables. Only very high dose of phosphorus fertilization $140 \mathrm{~kg} \mathrm{P}_{2} \mathrm{O}_{5} \mathrm{ha}^{-1}$ induced important enlargement of seed yield. Plant variables had also major association with seed yield categories. The increase of aphids induced a negative impact on seed yield, while an increase of the NDVI value significantly increased seed yield. Positive signs of coefficients of cultivars (Batuta, Meceans, Tarchalska) and NDVI proved a positive relationship between these predictors and the dependent variable (seed yield). As this variable increases, so does the probability of being in one of the higher categories of the seed weight category.

\section{Discussion}

During growth season, the mean number of aphids amounted to about 3 to 20 aphids per stem and varied markedly between the years of study. In their studies on six pea cultivars, Soroka and Mackay (1990a) recorded between 4.8 and 48.5 aphids per plant tip or stem, depending on the cultivar and the phase of growth of plant. For lucerne (Medicago sativa Linn.), the economic threshold level was calculated to be 85 aphids per stem (Kulkarni, 2016), while in the critical period (up to two weeks before harvest) - 12 aphids per stem (Cuperus et al., 1982). Therefore the numbers of aphids found in this study was not very high.

The rate of population growth in aphids is closely related to air temperature, and precipitation (particularly sudden rains which can wash down the insects from plants). In the optimum range of temperatures, the population growth of $A$. pisum, increases along with temperature. As proved by Morgan et al. (2001), the optimum ranges of temperatures can differ slightly between the cultivars (e.g. for Sancho cultivar: $11.9-23.1^{\circ} \mathrm{C}$, and for Scout cultivar 11.9$19.6^{\circ} \mathrm{C}$ ). In our studies, the principal population growth period was in June and July. The highest numbers of aphids were noted in 2015. It was a year with very dry June and July, accompanied by high mean air temperatures in these months (hydrothermal index $\mathrm{K}=0.300$ for June, and $\mathrm{K}=0.348$ for July). Such conditions favour the rapid development of aphid populations.

The lowest numbers of aphids were observed on Protecta and Tinker cultivars while the plants of Model cultivar were colonized by highest numbers. Protecta and Tinker cultivars display, respectively, high and very high resistance to pests (Selen seed company, http://selgen.eu/legumes/field-peas/protecta/, last accessed: 18.02.2018) which is reflected in the numbers of aphids observed. No similar feature was found in the description of Model forage cultivar. In the field conditions, the numbers of aphids on various cultivars of the same host plant can depend, inter alia, by a preference among winged migrant females to colonise a particular cultivar and by the effect of nutritive value of a cultivar upon developmental parameters (fertility, life span, the population intrinsic growth rate). When selecting a host plant, aphids follow the colour among other features. It has been proven that the aphids prefer plants of intensive green colour and a high protein content (Döring, 2014). The cultivars that we tested differ in both colour of leaves, as well as in the protein content. Model cultivar is characterised by higher protein content that Tarchalska, Batuta, or Mecenas cultivars (FAPA, 2015; Podleśny and Bieniaszewski, 2012). Additionally, the colour of leaves of Model cultivar was intensive green, which might have impacted on aphids preference. As concerns the effect of cultivar on the developmental parameters of aphids, the data in publications are diverse. Bieri et al. (1983) did
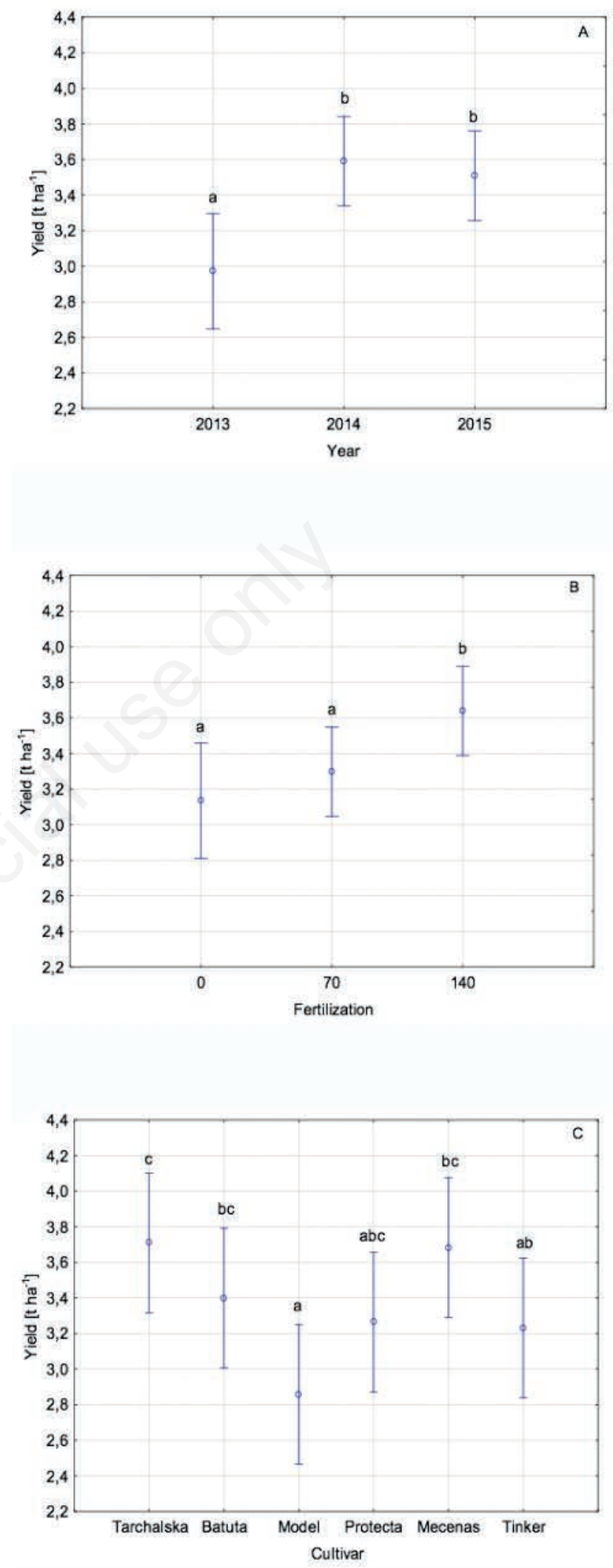

Figure 6. Mean yield of different pea cultivars cultivated at increasing doses of phosphorus fertilization $\left(0,70\right.$, and $\left.140 \mathrm{~kg} \mathrm{P}_{2} \mathrm{O}_{5} \mathrm{ha}^{-1}\right)$ in the years 2013-2015. One-way analysis, factors: year (A); fertilization (B); cultivar (C). Vertical bars denote 0.95 confidence intervals. Means followed by the same letters are not significantly different according to the least significant difference test $(P<0.05)$. 
not find the effect of pea cultivar (among 6 cultivars tested under both laboratory and field conditions) on the development of pea aphid. Also Sandstrom (1994) when studying the performance of one clone of the pea aphid on 37 different cultivars and species of Pisum, did not find significant differences in the mean relative growth rate between wild and cultivated Pisum species or between modern and old P. sativum cultivars. Soroka and Mackay (1990a) when analysing six field pea cultivars with respect to the development of A. pisum aphids in field cage tests showed, however, the significant differences between two cultivars: Trapper and Century. Retaining the same initial numbers of aphids, they obtained much larger aphid colonies on Trapper cultivar which resulted in lower number of pods. Morgan et al. (2001) also found that the population growth of $A$. pisum differed between two cultivars (Sancho and Scout).

In our study, phosphorus fertilization in a $70 \mathrm{~kg} \mathrm{ha}^{-1}$ dose favoured the occurrence of aphids in the case of most analyzed cultivars whereas the twice-higher dose limited that effect. The lowest number of aphids was usually recorded in the object without phosphorus fertilization. In insects, phosphorus is essential for the ATP, RNA, DNA syntheses and, therefore, for the production of proteins. Studies by Barker and Tauber (1951) showed that pea aphids had higher fertility when feeding on pea growing on a complete nutrient diet than on plants deficient in $\mathrm{N}, \mathrm{P}, \mathrm{K}, \mathrm{Ca}$ or $\mathrm{Mg}$. Similarly, the lowest numbers of Aphis fabae Scop. aphids were noted on the broad bean plants with the lowest content of phosphorus (Nadgórska-Socha et al., 2005; Gospodarek and Kafel, 2014). The surplus of phosphorus can lead to the lower availability of nitrogen to plants. The increase in phosphorus content in Plantago lanceolata L. plants, resulting from the applied mycorrhiza, was coupled with the accelerated growth of the green peach aphid (Myzus persicae Sulzer), but only when plants were accompanied by earthworms (Aporrectodea caliginosa, Savigny) limiting the action of mycorrhiza towards the uptake of nitrogen. Neither the presence of earthworms, nor the mycorrhiza occurring separately showed that effect, quite to the opposite - they inhibited the development of aphids (Wurst et al., 2004). As it is known, nitrogen is responsible for the intensive green colour of plants, preferred by aphids during incursions, and it also favour the development of aphids (Honêk and Martinkova, 2002; Davies et al., 2004). Thus the limiting impact of higher dose of phosphorus $\left(140 \mathrm{~kg} \mathrm{ha}^{-1}\right)$ upon the occurrence of aphids can be partly explained by the effect of phosphorus on the nitrogen management in plants. Similar indirect effect of potassium on the nitrogen management in canola (Brassica napus L.) plants resulting in changes in M. persicae density was found by Severtson et al. (2016).

In response to the excessive population density, or the worsening of nutritive value of host plant, winged migrant females can appear in the population, which then fly away in search for better food source (Hardie, 1980). The mean number of winged form of A. pisum was positively correlated with the total number of aphids in the case of Tarchalska and Mecenas cultivars whereas in the case of Batuta, Protecta, and Tinker cultivars, more winged forms were noted when the higher doses of phosphorus fertilization were applied. This fact may testify to the worsening feeding conditions for $A$. pisum in these cultivars, with higher dose of phosphorus applied. It should be remembered that Protecta and Tinker cultivars had the lowest number of aphids, therefore the phenomenon of the excessive population density was not likely the factor causing the appearance of higher number of winged individuals.

Romano et al. (2011) considered that NDVI was a promising method to select genotypes adapted to the conditions of drought. In field conditions, plants react to water shortage in various ways. It is a well-known fact that leguminous plants during the flowering stage show the greatest requirements for water. On the basis of their analysis of regression trees, Zheng et al. (2010) proved that in the condition of soil drought, the productivity of soybean plants is conditioned on the quantity of phosphorus applied. Similar results were obtained by Klimek-Kopyra et al. (2016) who indicated that phosphorus had significant importance in the increase of productivity of plants under temporary soil drought. The above results were confirmed in our experiment because the significant impacts of phosphorus and weather conditions were forecasted through NDVI. In wet year, the increase of phosphorus fertilization gave maximum NDVI value (0.68). Additionally, the results suggested that phosphorus treatment $\left(140 \mathrm{~kg} \mathrm{ha}^{-1}\right)$ and cultivar Protecta gave maximum NDVI value among all treatments.

Baigorri et al. (1999) found that in the conditions of water deficit, the translocation of assimilates is lower in leafy cultivars because the plants just boost their chances to survive by doing so. In turn, Alvino and Leone (1993) proved that afila type cultivar show higher resistance to drought. In our study a high dose of phosphorus was applied with the aim to verify whether, under the stress conditions, the pea plants are capable of minimizing the stress via increased amount of phosphorus. The studies revealed the significant variability between cultivars conditioned by the environment. Among the compared cultivars, the highest variability in the value of NDVI was that of leafy Protecta cultivar, as well as the afila type cultivar, Tinker. The excessive amount of precipitation water during the flowering phase (in 2013) resulted in a significant increase in the value of NDVI in the leafy Protecta cultivar when without phosphorus fertilization, as well as in the afila type cultivar with the optimum level of fertilization. The increased soil drought, observed in 2015, revealed a different reaction. The leafy cultivar Protecta got the maximum value of NDVI after the highest dose of phosphorus was applied whereas the afila type cultivar Tinker - in control conditions.

Using remote sensing instruments, it is possible to monitor changes in crop health over the course of a growing season (Richardson et al., 2004). The presence of insect feeding on a plant or canopy surface causes changes in chlorophyll, chemical concentrations, cell structure, nutrient and water uptake, and gas exchange, which leads to differences in color and temperature that can modify canopy reflectance characteristics (Raikes and Burpee, 1998). Kumar et al. (2010) indicated that spectral indices of NDVI, had a significant correlation with aphids infestation. The authors suggested that indices could be used for identifying aphid infestation in mustard. Similar findings were presented by Elliott et al. (2015) who investigated the potential of multispectral remote sensing to provide quick and inexpensive information on sugarcane aphid pest status in sorghum fields. The authors proved that high NDVI indicates low levels of stress and low NDVI indicates high stress. NDVI ranged from -0.07 to 0.26 among fields. The correlation between NDVI and plant injury rating was negative and significant, as was the correlation between NDVI and the plant growth stage. The authors explained this first effect as a result of increased plant stress under the influence of increased aphids injuries. As confirmed also by other authors (Zhao et al., 2003; Kizil et al., 2012; Severtson et al., 2016) the increase in the level of plant stress is coupled with the drop in the value of NDVI. Reduced NDVI with increasing plant growth probably resulted from reduced photosynthetic activity in more mature plants. In our study, the coefficient of correlation between the value of NDVI and the number of aphids assumed different values depending on the season of studies. Only in 2013, the significant, negative relationships were found between these parameters, which is consis- 
tent with findings by other authors pertaining to the suitability of NDVI to the analysis of intensity of aphid occurrence on plants (Elliot et al., 2015; Guolong et al., 2016). The NDVI index is also used for a rapid assessment of the effect of the level of fertilization upon the condition of plants. The research on the topic, with respect to the potassium deficiency, was carried out by Severtson et al. (2016) on canola. These authors found that the potassium deficiency was associated, inter alia, with the increase in green peach aphid density, and with the lowered value of NDVI.

The other than expected values of the correlation coefficient in the 2015 season can be linked to the relationship between the NDVI and meteorological conditions, particularly with the supply of water (Kizil et al., 2012). In 2015, June was very dry, which can explain the low values of NDVI, July was somewhat more humid, and - in consequence - the value of NDVI was higher. In June of 2015 , the population of aphids was lower than that in July - here the reason was just the lack of intensive rains in the second half of June and in the beginning of July and, therefore, an undisturbed growth of aphid population. Furthermore, as proved by Pena and Altmann (2009) in the case of cypress aphid Cinara cupressi, the clear decrease in the NDVI occurs only when this pest inflicts severe damage while, with the mid-level damage, no significant relationship between the number of aphids and the value of NDVI can be found. The authors thus draw the conclusion that this index is useful to detect only severe damage, which matches our findings. The mean number of aphids in our experiment (3 to 20 aphids per stem) was relatively low.

Klimek-Kopyra et al. (2018) demonstrated the significant relationship between seed yield and vegetative indices (NDVI), depending on cultivar type and weather. The value of pea NDVI for investigated growth stages (flowering, the flat-pod phase of the maturity stage) indicated notable differences between the compared varieties of pea. $\mathrm{Cv}$. Klif, characterized by standard foliage, indicated considerably higher values of NDVI. The value of NDVI was dependent on weather conditions; therefore the higher values (0.64-0.79) were recorded in more humid years.

In summary, our results indicate that among many factors that determine the condition of the plant, NDVI index is more strongly modified by the cultivar, season and level of fertilization, than through the level of aphid infestation. Our findings confirm also the significant and cultivar dependent effect of phosphorus fertilization on the level of pea infestation by $A$. pisum aphids and this way, fill in some shortfall in the research investigating the effects of $\mathrm{P}$ fertiliser on ecosystems, what is emphasized in the literature (Buttler et al., 2012).

\section{Conclusions}

1. The studied cultivars differed with respect to the numbers of aphids on plants - the least colonised by aphids were Protecta and Tinker cultivars whereas the most intensively colonised was Model cultivar.

2. Independent of the dose, the phosphorus fertilization supported the occurrence of aphids on pea plants of Batuta, Model, and Protecta cultivars where in Tarchalska and Mecenas cultivars only the standard dose $\left(70 \mathrm{~kg} \mathrm{ha}^{-1}\right)$ showed such effect. In the case of Tinker cultivar, no effect of phosphorus fertilization on the numbers of aphids was found.

3. NDVI index was not clearly, unambiguously correlated to the intensity of $A$. pisum occurrence. Such factors as the deficiency or excessive amount of phosphorus, as well as meteorological con- ditions and the cultivar of host plant had the greater effect on its value than the presence of aphids. All this testifies that the NDVI index is not reliable indicator of aphid occurrence on pea in regular field condition.

4. The seed yield was strongly related to agronomical factors (fertilization, cultivars) and the plant (NDVI) variable, while marginally to the environmental variable (aphids). An increase in fertilization from 0 to $140 \mathrm{~kg} \mathrm{ha}^{-1}$ induced an important enlargement of seed yield; whereas an increase of aphids induces a negative impact on seed yield. The regression ordinal model proved a significant and positive relationship between cultivars (Batuta, Meceans, Tarchalska), NDVI, and the dependent variable (seed yield). As this variable increases, so does the probability of being in one of the higher categories of the seed yield. Conversely, negative estimates (aphids) indicated an inverse relationship. An increase of the aphids predisposes a pea seed to be classified to the lower outcome variable categories.

5. NDVI index can offer a promising method to select the cultivars under sub-optimal conditions. In the conditions of water deficit, applying phosphorus had a significant effect on the increase of NDVI in the leafy cultivar of pea.

\section{References}

Alvino A, Leone A, 1993. Response to low soil water potential in pea genotypes (Pisum sativum L.) with different leaf morphology. Sci. Hortic. 53:21-34.

Akhtar N, Amjad M, Anjum M, 2003. Growth and yield response of pea (Pisum sativum L.) crop to phosphorus and potassium application. Pak. J. Agri. Sci. 40:217-22.

Annan IB, Ampong-Nyarko K, Tingey WM, Schaefers GA, 1997. Interactions of fertilizer, cultivar selection, and infestation by cowpea aphid (Aphididae) on growth and yield of cowpeas. Int. J. Pest Manag. 43:307-12.

Asiwe JAN, 2009. The impact of phosphate fertilizer as a pest management tactic in four cowpea varieties. Afr. J. Biotechnol. 8:7182-6.

Baigorri H, Antolín MC, Sanchez-Diaz M, 1999. Reproductive response of two morphologically different pea cultivars to drought. Eur. J. Agron. 10:119-28.

Barker JS, Tauber OE, 1951. Fecundity of and plant injury by the pea aphid as influenced by nutritional changes in the garden pea. J. Econ. Entomol. 44:1010-2.

Butler J, Garratt M, Leather S, 2012. Fertilisers and insect herbivores: a meta-analysis. Ann. Appl. Biol. 161:223-33.

Bieri M, Baumgartner J, Bianchi G, Delucchi V, von Arx R, 1983. Development and fecundity of pea aphid (Acyrthosiphon pisum Harris) as affected by constant temperature and by pea cultivars. Bull. Soc. Entomol. Suisse. 56:163-71.

Cherszkowicz E, 1971. Hydrothermisher koeffizient (HTK) VI, VII, VIII. Karte. Agraklimatische ressurcen des territoriums der sozialstischen lander Europas. Sofia, pp.123.

Colomb B, Kiniry JR, Debaeke P, 2000. Effect of soil phosphorus on leaf development and senescence dynamics of field-grown maize. Agron. J. 92:428-35.

Cuperus CW, Radcliffe EB, Barnes DK, Marten GC, 1982. Economic injury levels and economic thresholds for pea aphid, Acyrthosiphon pisum (Harris) on alfalfa. Crop Sci. 1:453-63.

Davies Jr FT, Chunajiu H, Chau A, Heinz KM, Cartmill AD, 2004. Fertility affects susceptibility of chrysanthemum to cotton aphids: Influence on plant growth, phothosynthesis, ethylene 
evolution, and herbivore abundance. J. Am. Soc. Hort. Sci. 129:344-53.

Döring TF, 2014. How aphids find their host plants, and how they don't. Ann. Appl. Biol. 165:3-26.

Dubey YP, Kaistha BP, Jaggi RC, 1999. Influence of irrigation and phosphorus on growth, green pod yield and nutrient uptake of pea (Pisum sativum) in Lahaul Valley of Hiamachal Pradesh. Indian J. Agron. 44:137-40.

Elliott NC, Backoulou GF, Brewer MJ, Giles KL, 2015. NDVI to Detect Sugarcane Aphid Injury to Grain Sorghum. J. Econ. Entomol. 108:1452-5.

FAPA, 2015. Selected issues of legume cultivation, in: Księżak, J. (Ed.), Fundacja Programów Pomocy dla Rolnictwa, Warszawa, pp. 60. Polish.

Goławska S, 2010. Effect of various host-plants on the population growth and development of the pea aphid. J. Plant Prot. Res. 50:224-8.

Gospodarek J, 2005. The effect of zinc on development of Aphis fabae Scop. Post. Ochr Roś/ Progr. Plant Protect. 45:680-2. Polish.

Gospodarek J, Kafel A, 2014. Coexistence of Aphis fabae Scop. predators on broad bean growing on soil pollution with heavy metals. J. Elem. 19:95-108.

Gospodarek J, Nadgórska-Socha A, 2016. Chemical composition of broad beans (Vicia faba L.) and development parameters of black bean aphid (Aphis fabae Scop.) under conditions of soil contamination with oil derivatives. J. Elem. 21:1359-76.

Grzebisz W. 2015. Crop Production, Technology of crop production, Hortpress, Warszawa.

Guolong Zhang, Xu Tao, Ze Zhang, Yinxi Du, Xin Lü, 2016. Monitoring of Aphis gossypii using Greenseeker and SPAD Meter. J. Indian Soc. Remote Sens. 45:361-7.

Gupta CR, Sengar SS, Singh J, 2000. Growth and yield of table pea (Pisum sativum L.) as influenced by levels of phosphorus and lime in acidic soil. Vegetable Sci. 27:101-2.

Hardie J, 1980. Behavioral differences between alate and apterous larvae of the black bean aphid, Aphis fabae, dispersal from the host plant. Entomol. Exp. Appl. 28:697-710.

Honêk A, Martinkova Z, 2002. Factors of between- and within-plant distribution of Metopolophium dirhodum (Hom. Aphididae) on small grain cereals. J. Appl .Entomol. 126:378-83.

Jansson J, Ekbom B, 2002. The effect of different plant nutrient regimes on the aphid Macrosiphum euphorbiae growing on petunia. Entomol Exp Appl. 104:109-16.

Jasińska Z, Kotecki A, 2003. Detailed tillage of plants. Wrocław: Ed. Akademia Rolnicza we Wrocławiu.

Kizil U, Genc L, Inalpulat M, Sapolyo D, Mirik M, 2012. Lettuce (Lactuca sativa L.) yield prediction under water stress using artificial neural network (ANN) model and vegetation indices. Zemdirbyste-Agriculture 99:409-18.

Klimek-Kopyra A, Skowera B, Zając T, Grygierzec B, 2016. Development and production response of edible and forage varieties of pea (Pisum sativum L.) to temporary soil drought under different levels of phosphorus application. Acta Agrobot. 69:1-13.

Klimek-Kopyra A, Jacek S, Zając T, Neugschwandtner R, Klimesova J, 2017. Ordinal regression model for pea seed mass. Bodenkultur: J. Land Manage. Food Environ. 68:81-7.

Klimek-Kopyra A, Zając T, Oleksy A, Kulig B, 2018. Value of different vegetative indices (NDVI, GAI) usage in assessment of productive 2 potential of pea (Pisum sativum L.) at different growth stages under varying 3 management practices. Acta Agrobotan. 2:1-9.
Kulkarni NS, 2016. Loss estimation and economic threshold level for aphids (Acyrthosiphon pisum Harris) in lucerne. Range Manag. Agrofor. 37:113-5.

Kumar J, Vashisth A, Sehgal VK, Gupta VK, 2010. Identification of aphid infestation in mustard by hyperspectral remote sensing. J. Agric. Physics. 10:53-60.

Ma BL, Morrison MJ, Dwyer LM, 1996. Canopy light reflectance and field greenness to assess nitrogen fertilization and yield of corn. Agronomy J. 88:915-20.

McCullagh P, Nelder JA, 1989. Generalized linear models. Chapman \& Hall, New York, USA.

Mengel K, Kirkby EA, 1982. Principles of Plant Nutrition, 3rd edition. International Potash Institute, Worblaufen-Bern, Switzerland.

Mkhabela MS, Bullock P, Raj S, Wang S, Yang Y, 2011. Crop yield forecasting on the Canadian Prairies using MODIS NDVI data. Agric. Forest Meteorol. 3:385-93.

Morgan D, Walters KFA, Aegerter JN, 2001. Effect of temperature and cultivar on pea aphid, Acyrthosiphon pisum (Hemiptera: Aphididae) life history. B. Entomol. Res. 91:47-52.

Nadgórska-Socha A, Gospodarek J, Jaworska M, Ciepał R, 2005. Content of assimilation pigments, phosphorus and protein in broad bean Vicia faba L. ssp. maior grown in heavy metals contaminated soils. Ecol. Chem. Eng. 12:421-6.

Onema JM, Taigbenu A, 2009. NDVI-rainfall relationship in the Semliki watershed of the equatorial Nile. Phys. Chem. Earth. 34:711-21.

Parsad RN, Multhoo AK, Mauryo AN, 1989. A note on the effect of phosphate fertilization on growth, nodulation and green pod yield of pea. Haryana J. Hart. Sci. 16:142-4.

Pinter Jr PJ, Hatfield JL, Schepers JS, Barnes EM, Moran MS, Daughtry CST, Upchurch DR, 2003. Remote sensing for crop management. Photogramm. Eng. Rem. S. 69:647-64.

Pena MA, Altmann SH, 2009. Recognition of the effect of Cinara cupressi (Hemiptera: Aphididae) in the sanitary condition of Austrocedrus chilensis by multispectral images. Bosque 30:151-8.

Pitan OOR, Odebiyi JA, Adeoye GO, 2000. Effects of phosphate fertilizer levels on cowpea pod-sucking bug populations and damage. Int. J. Pest Manage. 46:205-209. Podleśny J, Bieniaszewski T, 2012. Evaluation on pea (Pisum sativum L.) yielding at different region of Poland. Fragmenta Agronom. 29:125-35 [Article in Polish].

Ponzoni FJ, Goncalves JL, 1999. Spectral features associated with nitrogen, phosphorous, and potassium deficiencies in Eucalyptus saligna seedling leaves. Int. J. Remote Sens. 20:2249-2264.

Raikes C, Burpee LL, 1998. Use of multispectral radiometry for assessment of Rhizoctonia blight in creeping bentgrass. Phytopathology. 88:446-9.

Richardson AD, Aikens M, Berlyn GP, Marshall P, 2004. Drought stress and paper birch (Betula papyrifera) seedlings: effects of an organic biostimulant on plant health and stress tolerance, and detection of stress effects with instrument-based, noninvasive methods. J. Arboricult. 30:52-61.

Romano G, Zia S, Spreer W, Cairns J, Araus J, Muller J, 2011. Use of thermography for high throughput phemotyping of tropical maize adaptation in water stress. Comput. Electron. Agric.79:67-74.

Rouse JW, Haas RH, Schell JA, Deering DW, 1973. Monitoring vegetation systems in the Great Plains with ERTS, in: 3rd ERTS Symposium. NASA SP-351 I:309-17.

Rusin M, Gospodarek J, Nadgorska-Socha A, Barczyk G, 2017. 
Effect of petroleum-derived substances on life history traits of black bean aphid (Aphis fabae Scop.) and on the growth and chemical composition of broad bean. Ecotoxicology 26:308-19.

Rusin M, Gospodarek J, Nadgorska-Socha A, Barczyk G, Boliglowa E, Dabioch M, 2018. Effect of petroleum-derived substances on life history traits of bird cherry-oat aphid (Rhopalosiphum padi L.) and on the growth and chemical composition of winter wheat. Environ. Sci. Pollut. R. 25:27000-12.

Sandstrom J, 1994. High variation in host adaptation among clones of the pea aphid, Acyrthosiphon pisum on peas, Pisum sativum. Entomol. Exp. Appl. 71:245-56.

Saucke H, Juergens M, Doring TF, Fittje S, Lesemann DE, Vetten HJ, 2009. Effect of sowing date and straw mulch on virus incidence and aphid infestation in organically grown faba beans (Vicia faba). Ann. Appl. Biol. 154:239-50.

Severtson D, Callow N, Flower K, Neuhaus A, Olejnik M, Nansen C, 2016. Unmanned aerial vehicle canopy reflectance data detects potassium deficiency and green peach aphid susceptibility in canola. Precis. Agric. 17:659-77.

Shanahan JF, Holland KH, Schepers JS, Francis DD, Schlemmer MR, Caldwell R, 2003. Use of a crop canopy reflectance sensor to assess corn leaf chlorophyll content. ASA Special Publ. 66:135-50.

Solari F, Shanahan J, Ferguson RB, Schepers JS, Gitelson AA, 2008. Active sensor reflectance measurements of corn nitrogen status and yield potential. Agronomy J. 100:571-9.

Soroka JJ, Mackay PA, 1990a. Growth of pea aphid, Acyrthosiphon-pisum (Harris) (Homoptera, Aphididae), popu- lations on caged plants of 6 cultivars of field peas and the effects of pea aphids on harvest components of caged field peas. Can. Entomol. 122:1193-9.

Soroka JJ, Mackay PA, 1990b. Seasonal occurrence of the pea aphid, Acyrthosiphon-pisum (Harris) (Homoptera, Aphididae), on cultivars of field peas in manitoba and its effects on pea growth and yield. Can. Entomol. 122:503-13.

Toth G, Guicharnaud RA, Toth B, Hermann T, 2014. Phosphorus levels in croplands of the European Union with implications for P fertilizer use. Eur. J. Agron. 55:42-52.

Waring GL, Cobb NS, 1992. The impact of plant stress on herbivore population dynamics. In: Bernays E.A. (Ed.), Insect Plant Interactions. CRC Press, Florida, IV:167-226.

Wiatrak P, 2013. Influence of seed coating with micronutrients on growth and yield of winter wheat in southeastern coastal plains. Am. J. Agric. Biol. Sci. 8:230-8.

Wurst S, Dugassa-Gobena D, Langel R, Bonkowski M, Scheu S, 2004. Combined effects of earthworms and vesicular - arbuscular mycorrhizas on plant and aphid performance. New Phytologist. 163:169-76.

Zhao D, Reddy KR, Kakani VG, Read JJ, Carter GA, 2003. Corn (Zea mays L.) growth, leaf pigment concentrations, photosynthesis and leaf hyperspectral reflectance properties as affected by nitrogen supply. Plant Soil. 257:205-17.

Zheng H, Chen L, Han X, Xinfeng Z, 2010. Effectiveness of phosphorus application in improving regional soybean yields under drought stress: A multivariate regression tree analysis. Afr. J. Agric. Res. 5: 3251-8. 